\title{
HPLC EVALUATION OF THE ASCORBIC ACID CONTENT OF ROMANIAN FRUITS AND VEGETABLES FROM RETAIL MARKETS
}

\author{
CERASELA ELENA GÎRD ${ }^{1 *}$, IOANA NENCU ${ }^{1 * *}$, LIGIA ELENA DUŢU ${ }^{1 \#}$, MARIA \\ LIDIA POPESCU $^{1 \#}$, TEODORA COSTEA ${ }^{1 \#}$, ALEXANDRA FILARETA NEAGU $^{2 \#}$
}

"Carol Davila” University of Medicine and Pharmacy, Faculty of Pharmacy, 6 Traian Vuia Street, 020956, Bucharest, Romania

${ }^{I}$ Pharmacognosy, Phytochemistry and Phytotherapy Department

${ }^{2}$ Analytical Chemistry Department

*corresponding author: ioanaitudor@gmail.com

\#All authors have equal contribution

Manuscript received: March 2018

\begin{abstract}
The aim of our study was to evaluate the ascorbic acid content of some fruits (apricot, black and white currant, cherry, sour cherry, lime, lemon, nectarine, orange, pomegranate, kiwi, raspberry) and vegetables (parsley, dill, tomato) purchased from Romanian markets in order to evaluate their nutritional value. The chemical determination was carried on using a HPLC-UV-DAD (high-performance liquid chromatography ultraviolet-photodiode array) method, and the results were expressed as mg ascorbic acid/100 g fresh weight. Our results indicate that only for lime, tomato and parsley the ascorbic acid content comply with other reported data. The ascorbic acid content of fruits and vegetables varies depending on different factors, related to plant (species, cultivar, size of fruits), environment (climate, variation in sunshine, rainfall) or processing technologies (method of ripening, storage).
\end{abstract}

\section{Rezumat}

Scopul acestei lucrări a constat în evaluarea conţinutului de acid ascorbic al unor fructe (caise, coacăze albe şi negre, cireşe, vişine, lime, lămâi, nectarine, portocale, rodii, kiwi şi zmeură) şi legume (pătrunjel, mărar şi roşii) achiziţionate din magazine de tip supermarket din România, în vederea stabilirii valorii nutritive ale acestora. Determinarea acidului ascorbic s-a efectuat printr-o metodă cromatografică, de tip HPLC-UV-DAD (cromatografie de lichide de înaltă performanță cu detecție în ultraviolet, șir de fotodiode), iar rezultatele au fost exprimate în $\mathrm{mg}$ acid ascorbic/100 g de produs proaspăt. Conţinutul de acid ascorbic obţinut corespunde datelor din literatură doar în cazul limetei, roșiilor şi a pătrunjelului. Conţinutul de acid ascorbic al fructelor şi legumelor variază dependent de factori ce ţin de plantă (specie, soi, dimensiunea fructelor), mediu (climă, variaţia intensităţii luminii solare, precipitaţii) şi procesare (metodă de coacere, depozitare).

Keywords: ascorbic acid, fruits, vegetables, HPLC

\section{Introduction}

Vitamin $\mathrm{C}$ is one of the most important water-soluble vitamins, naturally presented in food. It is involved in many biological processes, for example: collagen synthesis, iron absorption and activation of the immune system $[11,25]$.

Epidemiological studies show that subjects with a high intake of vitamin $\mathrm{C}$ have a lower risk of chronic diseases. In fact, low intake of fruits and vegetables is the sixth on WHO's (World Health Organization) list of 20 risk factors for world-wide mortality [21, 25]. Dietary Reference Intake (DRI) for vitamin C, established by the Food and Nutrition Board of the Institute of Medicine, National Academy of Sciences (2002) is $90 \mathrm{mg} /$ day for males and $75 \mathrm{mg} /$ day for females, respectively [10, 24].

It is well-known that ascorbic acid content of fruits and vegetables is influenced by species, cultivar, climate, method and time of harvest, used fertilizers, storage and processing $[11,16,25]$. Mechanical damages that occur during harvesting are very common in fruit and vegetable handling. These can lead to injuries, trigger oxidative stress, which decreases raw material's quality. There are fruits (like apples and similar fruits) that show an obvious injury, but in cases of citrus fruits the damage is less visible [13].

On the other hand, it is known that high temperature decreases ascorbic acid content in fruits and vegetables [11]. According to Lee et al. (2000), in the case of tomatoes, the delay of 24 hours at $40^{\circ} \mathrm{C}$ between harvest and processing decreases with $12 \%$ the content of ascorbic acid. Nitrogen fertilizer at high rates tends to decrease the vitamin $\mathrm{C}$ content in oranges, lemons and mandarins, but potassium fertilizer increases ascorbic acid content [11].

Nowadays, most people do not have a home-garden to cultivate vegetables, therefore vegetables and fruits 
come from retail markets. Moreover, there is an increased demand for exotic fruits that are consumed after weeks of harvesting [4]. Therefore, it is important to establish the nutritional value of these foods and compare it to scientific data.

The aim of our study was to evaluate the ascorbic acid content of some fruits and vegetables purchased from Romanian markets, in order to assess their nutritional value.

Although, there is a lack of data regarding cultivar and specific geographical origin of our raw materials, this study may provide new data about the nutritional values of fresh fruits and vegetables found in Romanian supermarkets.

\section{Materials and Methods}

All chemicals were of analytical grade and purchased from Sigma-Aldrich (Germany). For ascorbic acid identification and quantification, standard of L-ascorbic acid was used (Sigma 99\% standard L-ascorbic acid). Preparation of samples

Fruits of Rubus idaeus (raspberry), Ribes nigrum (black currant), Ribes rubrum - yellow cultivar (white currant), Prunus cerasus (sour cherry), Prunus avium (cherry), Citrus aurantium (orange), Citrus limonum (lemon), Punica granatum (pomegranate), Citrus limetta (lime), Actinidia chinensis (kiwi), Prunus persica var. nucipersica (nectarine), Prunus armeniaca (apricots), Lycopersicum esculentum (tomato) and aerial parts of Petroselinum arvensis (parsley), Anethum graveolens (dill) were purchased from a retail market (Bucharest, Romania), between May - June, 2016. The raw materials were stored at $4{ }^{\circ} \mathrm{C}$ overnight, before the beginning of the experiments.

The working solutions were obtained according to Rădulescu et al. [20] protocol: $10.00 \mathrm{~g}$ raw material was minced using a ceramic mortar. Each minced raw material was mixed with $50 \mathrm{~mL}$ of $0.5 \%$ oxalic acid aqueous solution in an Erlenmeyer flask. The flasks were sonicated for 30 minutes in a MRC ultrasonic bath. The mixtures were filtered through a $0.45 \mu \mathrm{m}$ filter and $20 \mu \mathrm{L}$ of filtrate was injected in the HPLC (high-performance liquid chromatography) apparatus. HPLC analysis

For ascorbic acid analysis we have used a Jasco HPLC MD-2015 described in our previously published paper $[8,16]$. For the separation, a reverse-phase analytical column was employed (Nucleosil - C18 25 x $0.4 \mathrm{~mm}$ i.d, $5 \mu \mathrm{m}$ particle). A mobile phase consists of a mixture of $95 \%$ aqueous $\mathrm{NaH}_{2} \mathrm{PO}_{4}(0.05 \mathrm{M})$ adjusted to $\mathrm{pH} 3.6$ by adding $85 \%$ phosphoric acid with $5 \%$ methanol, in an isocratic elution. The wavelength detection was set at $242 \mathrm{~nm}$. The flow rate of the mobile phase was $0.7 \mathrm{~mL} / \mathrm{min}$ and the injected volume was $20 \mu \mathrm{L}$. The chromatographic data were processed using Chrompass from Jasco, Japan. The identification of ascorbic acid was made using the retention time and the UV spectrum. For quantification, a calibration curve was performed. The results were expressed as $\mathrm{mg}$ ascorbic acid/100 $\mathrm{g}$ of fresh weight (F.W.). Statistical analysis

All data are presented as mean \pm standard deviation of triplicate analysis, calculated using the Excel software package (2010).

\section{Results and Discussion}

The lack of stability of ascorbic acid in aqueous solution is well-known [20]. Attempts to establish the proper medium employed different acidic solvent (phosphoric acid $0.05 \%$, oxalic acid $0.5 \%$, lactic acid $0.5 \%$, meta-phosphoric acid 9\%) $[3,20]$. According to Rădulescu et al. (2013), an aqueous oxalic acid $0.5 \%$ doesn't affect ascorbic acid stability in solution, therefore we have used this solvent in our further experiments.

Using retention time (RT) and the UV spectrum, ascorbic acid $(\mathrm{RT}=9.04 \mathrm{~min})$ and oxalic acid $(\mathrm{RT}=$ $4.10 \mathrm{~min}$ ) were identified. The resolution between the two peaks was 15.93 , indicating a good separation (Figure 1). The ascorbic acid calibration curve showed good linearity $\left(\mathrm{R}^{2}=0.999\right)$ in the range of used concentrations $(2.64 \mu \mathrm{g} / \mathrm{mL}-79.20 \mu \mathrm{g} / \mathrm{mL})$ (Figure 2).

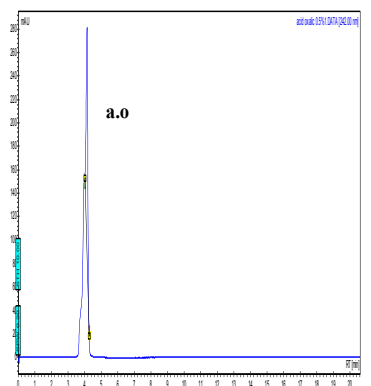

A

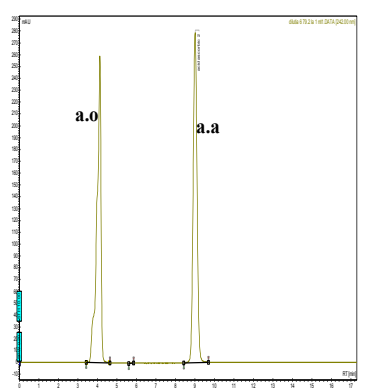

B
Figure 1.

Standard chromatograms:

A) oxalic acid (a.o); B) ascorbic acid (a.a) and oxalic acid

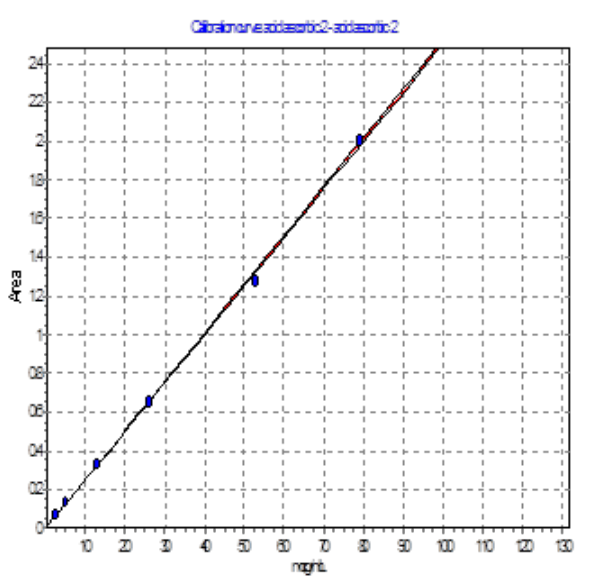

Figure 2.

Ascorbic acid calibration curve 
FARMACIA, 2018, Vol. 66, 5

Ascorbic acid content of samples and the selected chromatograms are shown in Table 1 and Figure 3. As expected, parsley aerial parts have the highest content of ascorbic acid, followed by black and white currant fruits and citrus fruits. In the case of vegetables, dill (13.71 mg/100 g F.W.) has a low content of ascorbic acid compared to parsley (100.98 mg/100 g F.W.). Citrus fruits have higher contents of ascorbic acid compared to raspberry, cherry, sour cherry, apricot, pomegranate and nectarine. Among citrus fruits, ascorbic acid content decreases in the following order: orange $>$ lemon $>$ lime.

Regarding data from scientific literature, there is a significant variance of ascorbic acid content in selected fruits and vegetables (Table 1) [1, 2, 6, 7, 9, 11-16, 18, 19, 22, 23, 25]. Except for lime, tomato and parsley, all the results fall below the data found by other authors $[3,18,23]$.

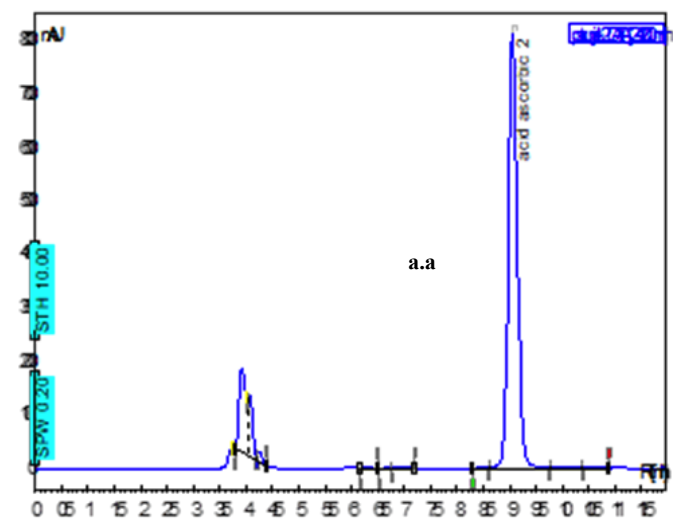

A
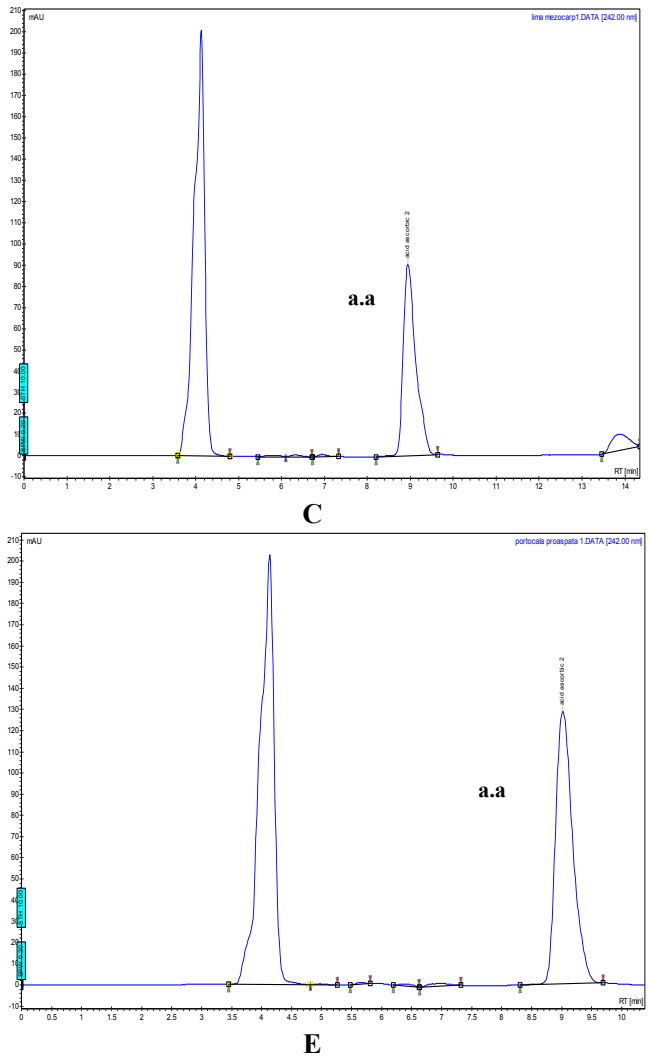

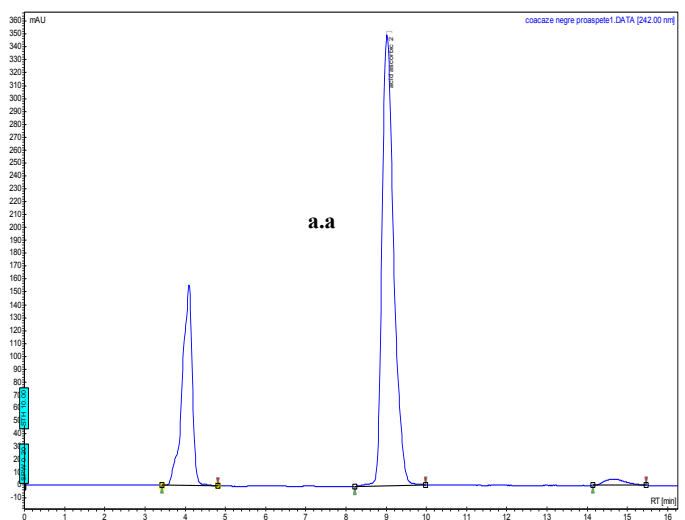

B

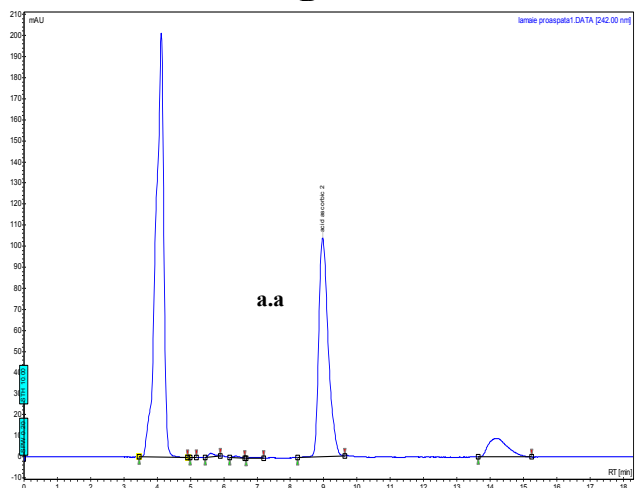

D

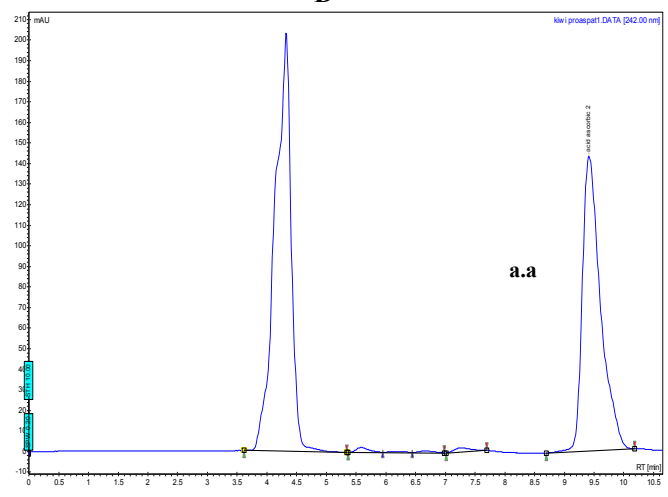

F

Figure 3.

Ascorbic acid (a.a) chromatograms: A) parsley; B) black currant; C) lime; D) lemon; E) orange; F) kiwi

Table I

Results of the quantitative analysis

\begin{tabular}{|l|c|c|}
\hline \multicolumn{1}{|c|}{ Raw material } & $\mathbf{m g} / \mathbf{1 0 0} \mathbf{g}$ & References mg/100 g \\
\hline Parsley & $130.98^{*}$ & $179.65[2]^{*}, 110-200[2,19]^{*}, 122[2,23]^{*}$ \\
\hline Dill & $13.71^{*}$ & $204.55[2]^{*}, 116[12]^{*}$ \\
\hline Tomato & $15.92^{*}$ & $10.02-16.16[3]^{*}$ \\
\hline
\end{tabular}


FARMACIA, 2018, Vol. 66, 5

\begin{tabular}{|c|c|c|}
\hline Raw material & $\mathrm{mg} / 100 \mathrm{~g}$ & References $\mathrm{mg} / \mathbf{1 0 0 \mathrm { g }}$ \\
\hline Apricot & $0.57 *$ & $4.79-7.14[15]^{*}, 3.04-16.17[5]^{*}$ \\
\hline Currant (black) & $70.71 *$ & $161.58-284.46[17]^{* *}$ \\
\hline Currant (white) & $44.15^{*}$ & $48.6[22]^{*}$ \\
\hline Cherry & $0.47 *$ & $1.92[1]^{*}, 7[11]^{*}, 6.01-11.04[9]^{*}$ \\
\hline Sour cherry & $0.75^{*}$ & $10[6]^{*}$ \\
\hline Lime & $20.49 *$ & $21[25]^{*}$ \\
\hline Lemon & $20.72 *$ & $50.4[11,13]^{*}$ \\
\hline Nectarine & $1,02 *$ & $3.5-6.1[7]^{*}$ \\
\hline Orange & $24.45^{*}$ & $33.3-38.2[3]^{*}$ \\
\hline Pomegranate & $1.83 *$ & $1.56[25]^{*}$ \\
\hline Kiwi & $20.88^{*}$ & $55.20-91.20[25]^{*}$ \\
\hline Raspberry & $11.17 *$ & $18.5-37.2[18]^{*}$ \\
\hline
\end{tabular}

*F.W. $=$ fresh weight; $* *$ D.W. - dried weight

A possible explanation resides in the diversity of the raw material (different species and cultivars, size and maturity of the fruits), different pre-harvest factors (climate, variation in sunshine, rainfall, humidity, soil, fertilizer) and different processing technologies (method of ripening, storage) [21, 25].

Another aspect worthy of mention is the fact that raw materials used in most of mentioned scientific research were fresh fruits and vegetables $[1,7,15,18$, $22]$. Therefore, we suppose that a long storage might be involved in ascorbic acid decrease in fruits and vegetables. In our case, we suppose that storage at room temperature in retail market led to the degradation of vitamin C. Our hypothesis is supported by Cotruţ \& Bădulescu report (2016), who founded similar results
(10.02 mg - $16.16 \mathrm{mg} / 100 \mathrm{~g} \mathrm{F.W.)} \mathrm{to} \mathrm{ours} \mathrm{(15.92} \mathrm{mg/}$ $100 \mathrm{~g} \mathrm{~F}$.W.) for tomato, purchased from a market store [3]. We consider that the vitamin $\mathrm{C}$ content from the analysed fruits and vegetable enables the required vitamin $\mathrm{C}$ intake.

According to the National Sanitary Surveillance Agency from Brazil, the solid food ready for consumption are classified as "source" or as "rich" when they provide more than $15 \%$ or $30 \%$ of the DRI, respectively, considering a mean daily consumption of $100 \mathrm{~g} /$ day [25]. In Figure 4 is shown the content of vitamin $C$ of our sample reported to the DRI. Based on this classification and in view of our results, parsley, black currant and white currant might be considered as "source", and dill, lime, lemon, orange, as "rich".

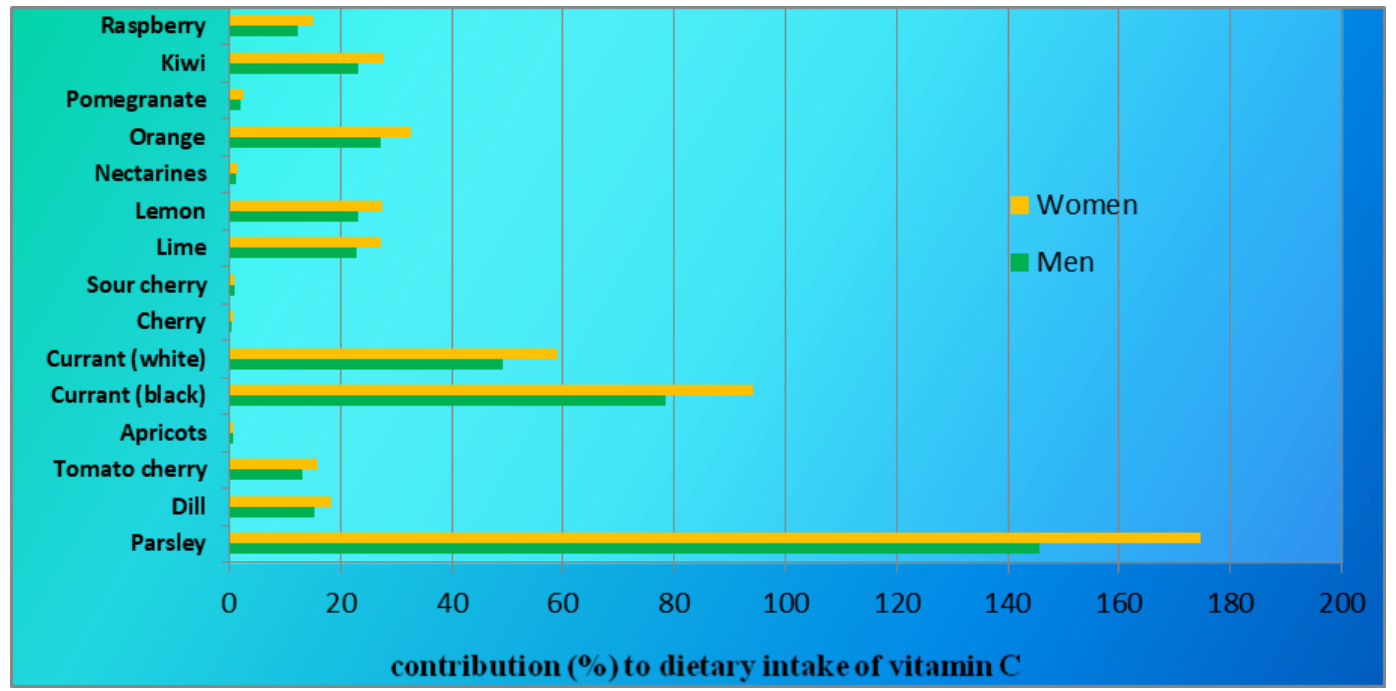

Figure 4.

Content of vitamin C (\%) of analysed samples reported to the DRI

\section{Conclusions}

In conclusion, our work assessed the ascorbic acid content of several fruits and vegetables from retail markets. The ascorbic acid content of tomato, lime and parsley comply with data found in scientific literature. In the case of dill, apricot, black and white currant, sour cherry, lime, lemon, nectarine, orange, pomegranate, kiwi and raspberry, the ascorbic content falls below the values found by other authors. Although, the species and the cultivar are not consistent with ones found in scientific literature, this study may provide new data regarding nutritional values of fresh fruits and vegetables marketed in Romanian retail stores. 


\section{References}

1. Bastos C, Barros L, Dueñas M, Calhelha CR, Queiroz MJ, Santos-Buelga C, Chemical characterization and bioactive properties of Prunus avium L.: the widely studied fruits and the unexplored stem. Food Chem., 2015, 173: 1045-1053.

2. Cătunescu GM, Tofană M, Mureşan C, Ranga F, David A, Muntean M, The effect of cold storage on some quality characteristics of minimally processed parsley (Petroselinum crispum), dill (Anethum graveolens) and lovage (Levisticum officinale). Bulletin UASVM Agriculture, 2012, 69(2): 213-221.

3. Cotruţ R, Bădulescu L, UPLC Rapid quantification of ascorbic acid in several fruits and vegetables extracted using different solvents. Agric Sci Procedia, 2016, 10: $160-166$.

4. El-Ramady HR, Domokos-Szabolcsy É, Abdalla NA, Taha HS, Fári M. Postharvest Management of Fruits and Vegetables Storage. In: Lichtfouse E. (eds) Sustainable Agriculture Reviews. Sustainable Agriculture Reviews, vol 15. Springer, 2015; Cham.

5. Engel R, Abranko L, Balogh E, Blazovics A, Herman R, Halasz J, Ercisli S, Pedryc A, Stefanovits-Banyai E, Antioxidant and antiradical capacities in apricot (Prunus armeniaca L.) fruits: variations from genotypes, years and analytical methods. J Food Sci., 2010, 75(9): C722-730.

6. Ferretti G, Bacchetti T, Belleggia A, Neri D, Cherry antioxidants: from farm to table. Molecules, 2010; 15: 6993-7005.

7. Gil M, Tomaä S, Barberaä FA, Hess-Pierce B, Kader AA, Antioxidant capacities, phenolic compounds, carotenoids, and vitamin $\mathrm{C}$ contents of nectarine, peach, and plum cultivars from California. J. Agric. Food Chem., 2002; 50: 4976-4982.

8. Gîrd CE, Nencu I, Popescu ML, Costea T, Duţu LE, Balaci TD, Olaru OT, Chemical, antioxidant and toxicity evaluation of rosemary leaves and its dry extract. Farmacia, 2017, 65(6): 978-983.

9. Gündoğdu M, Bilge U, Determination of organics, phenolics, sugars and vitamin $\mathrm{C}$ contents of some cherry cultivars (Prunus avium). Int J Agric Biol., 2012; 14(4): 559-599.

10. Institute of Medicine. Dietary reference intakes for vitamin $\mathrm{C}$, vitamin $\mathrm{E}$, selenium, and carotenoids. Washington, DC: The National Academies Press, 2000.

11. Lee SK, Kader AA, Preharvest and postharvest factors influencing vitamin $\mathrm{C}$ content of horticultural crops. Postharvest Bio Tech., 2000; 20: 207-220.

12. Lisiewska Z, Słupski J, Zuchowicz E, Effect of temperature and storage period on the preservation of vitamin $\mathrm{C}$, thiamine and riboflavin in frozen dill
(Anethum Graveolens L.). Electronic J Polish Agric Universities, 2003; 6(2): 67-75.

13. Mitchell GE, McLauchlan RL, Isaacs AR, Williams DJ, Nottingham SM, Effect of low dose irradiation on composition of tropical fruits and vegetables. $J$ Food Comp Anal., 1992; 5(4): 291-311.

14. Montero CRS, Schwarz LL, Cunha dos Santos L, Andreazza CS, Kechinski CP, Bender RJ, Postharvest mechanical damage affects fruit quality of 'Montenegrina' and 'Rainha' tangerines. Pesq Agropec Bras., 2009, 44 (12): 1636-1640.

15. Munzuroglua F, Geckil H, The vitamin and selenium contents of apricot fruit of different varieties cultivated in different geographical regions. Food Chem., 2003; 83: 205-212.

16. Nencu I, Istudor V, Ilies DC, Radulescu V, Preliminary research regarding the therapeutic uses of Urtica dioica L. Note II. The dynamics of accumulations of total phenolic compounds and ascorbic acid. Farmacia, 2013; 61(2): 276-283.

17. Nour V, Trandafir I, Ionică ME, Ascorbic acid, anthocyanins, organic acids and mineral content of some black and red currant cultivars. Fruits, 2011; 66(5): 353-362.

18. Pantelidis GE, Vasilakakis GA, Diamantidis Gr, Antioxidant capacity, phenol, anthocyanin and ascorbic acid contents in raspberries, blackberries, red currants, gooseberries and cornelian cherries. Food Chem., 2007; 102: 777-783.

19. Parthasarathy VA, Chempakam B, Zachariah TJ, Chemistry of Spices. Biddles Ltd, London, 2008; 376.

20. Rădulescu V, Ilieş DC, Voiculescu I, Biriş IA, Crăciunescu A, Determination of ascorbic acid in shoots from different coniferous species by HPLC. Farmacia, 2013; 61(6): 1158-1166.

21. Rickman CJ, Barrett MD, Bruhn MC, Nutritional comparison of fresh, frozen and canned fruits and vegetables. Part 1. Vitamins $\mathrm{C}$ and $\mathrm{B}$ and phenolic compounds. J Sci Food Agric., 2007; 87: 1185-1196.

22. Rodriguez R, Oderiz V, Hernandez L, Lozano S, Determination of vitamin $\mathrm{C}$ and organic acids in various fruits by HPLC. J Chromatogr Sci., 1992; 30(11): 433-437.

23. Peter V, Shylaja MR, Handbook of herbs and spices, vol I, Woodhead Publishing, London, 2012; 22.

24. Szeto YT, Tomlinson B, Benzie IF, Total antioxidant and ascorbic acid content of fresh fruits and vegetables: implications for dietary planning and food preservation. Br J Nutrition, 2002; 87: 55-59.

25. Valente A, Goncalves A, Sanches-Silva A, Costa $\mathrm{H}$, A contribution to produce quality data for food composition databases. Food Res Int., 2011; 44: 2237-2242. 